\title{
Erratum to: The Effect of Cadmium on Steroid Hormones and Their Receptors in Women with Uterine Myomas
}

\author{
Marzenna Nasiadek $\cdot$ Ewa Swiatkowska \\ Anna Nowinska • Tomasz Krawczyk • \\ Jacek R. Wilczynski • Andrzej Sapota
}

Published online: 1 July 2011

(C) Springer Science+Business Media, LLC 2011

Erratum to: Arch Environ Contam Toxicol (2011)

60:734-741

DOI 10.1007/s00244-010-9580-8

The original version of this article unfortunately contained a mistake. In the Abstract section, the sentence " $\mathrm{Cd}$ concentration in leiomyoma tissues was twice as high as that in surrounding myometrium ( 0.48 and $0.75 \mu \mathrm{g} \mathrm{Cd} / \mathrm{g}$ wet tissue, respectively), albeit the difference was not statistically significant." should read as follows: Cd concentration in leiomyoma tissues was twice as low as that in surrounding myometrium $(0.047$ and $0.075 \mu \mathrm{g} \mathrm{Cd} / \mathrm{g}$ wet tissue, respectively), albeit the difference was not statistically significant.

The online version of the original article can be found under doi:10.1007/s00244-010-9580-8.

M. Nasiadek $(\bowtie) \cdot$ A. Sapota

Department of Toxicology, Faculty of Pharmacy,

Medical University, 90-151 Lodz, Poland

e-mail: marzenna.nasiadek@umed.lodz.pl

E. Swiatkowska - A. Nowinska · T. Krawczyk ·

J. R. Wilczynski

Research Institute Polish Mother's Memorial Hospital,

93-338 Lodz, Poland 